\title{
The Sense of Self-Dignity of People with Mobility Disabilities in Poland-a Survey Report
}

\author{
Ewa Grudziewska ${ }^{1}$ (D) Marta Mikołajczyk ${ }^{1}$ (D) \\ Published online: 15 October 2020 \\ (C) The Author(s) 2020
}

\begin{abstract}
This article deals with the issue of the dignity and sense of personal dignity of people with disabilities in Poland. According to Statistics Poland, there are over 4.5 million people with disabilities. Although their situation is the subject of analysis conducted by representatives of various scientific disciplines, as well as of social welfare workers, education professionals, health care service workers, and legislators, there are relatively few studies on their understanding and experience of dignity. The presented text includes results of research carried out with a group of 98 people with disabilities. The diagnostic survey method was applied by using a questionnaire. The research tool was the Sense of Self-Dignity Questionnaire (KPWG-3) created by Stanisława Steuden and Paweł Brudek. The obtained empirical material indicates that the surveyed women with disabilities have a higher sense of self-dignity in comparison with the men with disabilities in the scope of the dimension of the disability loss and the total result. However, the studied men with disabilities have a superior self-dignity in the relation $(p<0.001)$ and experience $(p<0.05)$ dimensions. Moreover, when taking into account the time of occurrence of the disability, that is to say "congenital disability" vs "acquired disability", there were no statistically significant differences. In addition, the employment activity of the surveyed people with disabilities did not significantly differentiate the statistical result of the sense of self-dignity. However, there were dignificant differences based on level of education in the cognitive $(p<0.05)$ and experience $(p<0.001)$ dimensions, and in the general result $(p<0.05)$.
\end{abstract}

Keywords Disability $\cdot$ People with disabilities $\cdot$ Dignity $\cdot$ Sense of self-dignity

\section{Introduction}

According to the National Census of Population and Housing, completed in 2011 by Statistics Poland (Wysocka et al. 2011), there are more than four and a half million people with disabilities in Poland (12\% of the population). Among them, more than three million people have a disability certified by a competent authority. Others experience biological disability. This term is used by Statistics Poland when referring to people who do not have a certified disability, but they have (feel) a completely or seriously limited ability to perform basic activities appropriate for their age. Forty-six percent of all persons with disabilities are men and $11.2 \%$ of men with disabilities

Marta Mikołajczyk

mmikolajczyk@aps.edu.pl

Ewa Grudziewska

egrudziewska@aps.edu.pl

1 Institute of Social Prevention and Social Work, The Maria Grzegorzewska University, Szczęśliwicka St. 40, Warsaw, Poland are assessed as completely limited compared to $9.7 \%$ of women with disabilities.

A study by conducted by Statistics Poland also shows that the greatest number of people with disabilities, almost one and a half million, have primary education, and more than $1,184,000$ have a vocational education. Slightly fewer people hold secondary education-over 1,176,000 (including 122,000 who have secondary education without secondary school-leaving examination). The lowest number of the people have a university diploma - almost 350,000. At this point, it should be noted that the percentage of children with disabilities receiving any form of education in developing countries is very low (Stein 2007).

Experiencing disability and having a low level of education affect the source of income and subjective assessment of the financial situation. Over 3.5 million people with disabilities live on unearned sources of income (old age or disability pensions, benefits from social assistance), and more than 580,000 of them are employed (of which nearly 300,000 work in the private sector). Almost 390,000 are financially dependent on other people (Wysocka et al. 2011). 
According to a survey carried out by Statistics Poland in 2016 on households, those households in which there are no disabled people twice as often - in relation to those with people with disabilities - assess their own financial situation as very good (15.1\% and $7.4 \%$ respectively). The situation is opposite in case of negative opinions: $6.6 \%$ of the households with disabled people and $2.7 \%$ of the households with nondisabled people defined their situation as bad (Barlik et al. 2017).

Disabilities entail additional costs for health care services, assistive devices, costlier transportation options, heating, laundry services, special diets, or personal assistance in order to achieve a standard of living equivalent to that of nondisabled people (World Report on Disability 2011). We may even say that there is a link between disability and poverty (Pinilla-Roncancio 2015).

The cited data provoke reflection on the situation of people with disabilities. This situation is understood not only as an economic situation but also relating to living conditions in general: are they satisfactory? And, going further-is it a life with dignity? In the Polish literature on the subject, there are studies that address this issue, but they are usually limited to mentioning the difficulties faced by the people with disabilities and emphasizing violations of the principle of their self-determination or personalization (e.g. Dykcik 2009). However, there is a paucity of research in the area. This article is therefore an attempt to fill this gap.

\section{Dignity—Definitions}

Issues concerning human dignity are considered by representatives of various scientific disciplines. The concept of human dignity has an impressive history and tradition (Uwell et al. 2012). It is dealt with by ethicists, philosophers, psychologists, lawyers, doctors, or theologians who, though considering it from different perspectives, nevertheless underline that it shows the dimension and quality of a human being. Informally it means, among others: respect for oneself and others, subjectivity, autonomy, and experiencing one's own value (Mariański 2016). Dignity is given to us just by the very fact of being human. This statement is emphasized in legal documents of international and national scope (Misztal 2012). For example, the preamble of the Universal Declaration of Human Rights of the United Nations, adopted in 1948, emphasizes the "recognition of the inherent dignity and equal and inalienable rights of all members of the human community" (...). Inherited dignity is also underlined in the introduction to the 1989 Convention on the Rights of the Child (1989), in Protocol 13 to the Convention for the Protection of Human Rights and Fundamental Freedoms, concerning the abolition of the death penalty in all circumstances of 2002 and the
Charter of Fundamental Rights of the European Union in 2010. In the Constitution of the Republic of Poland of 1997 , it is stressed that dignity is congenital, inalienable, inviolable, and a source of freedom and human and civil rights.

According to Andrzej M. de Tchorzewski, it should be treated as the immanent property of every human person, as a one-of-a-kind value (de Tchorzewski 2016). In this sense, it is called personal/ontological dignity. There is also a personal dignity which is related to the actions taken by an individual, and in particular it refers to how the individual acts. The third aspect of dignity is its personal aspect which means an individual sense of a person's value, taking into account the person's roles, functions, and duties (ibid., p. 22).

Personal dignity appears to be a psychological variable consisting of self-respect, trust in oneself and one's own abilities, and full self-acceptance (Brudek and Steuden 2017). This is related to self-esteem, a person's system of values, and the ability of critically assessing oneself (Szczupał 2009). Based on the research findings presented in this article, it should be emphasized that personal dignity develops through interactions with other people as a result of undertaken activities. According to Adam Mikrut, the nature of personal dignity is not permanent. It is subject to changes, it changes its intensity, and it can even be destroyed - for example, as a result of living in humiliating conditions (Mikrut 2016; Friedman 2018). Wojciech Chudy defines personal dignity as a value associated with an individual's external relations, with one's social position, profession, and career path. He states that personal dignity is a result of social recognition or conferral, and of self-recognition and well-being (Chudy 2005, pp. 83-91).

Given the foregoing discussion, the aim of the study was to investigate the personal dignity of people with disabilities living in Poland. On the one hand, it can be assumed that since experiencing a disability often limits the possibilities of active participation in social life, the level of the sense of personal dignity will be low. On the other hand, thanks to the increasingly frequent social campaigns, and the progress of technology and medicine, their dignity might reach average or above average levels. To determine this, the results of existing analysis will be cited first, followed by the research carried out by the authors.

\section{Dignity of the People with Disabilities in Poland}

Disabilities are not experienced in a uniform manner. It depends on the form and severity of the disability, on the time of its occurrence, the individual's personality, living conditions (Wolski 2013), and on the attitude of the person and that of his/her environment (Szczupał 2009, p. 306). Disabilities limit 
people's functioning. Its consequences can be divided into psychological, health-related, professional, financial, and social aspects.

The first consequences refer to self-perception (also in comparison with others) or to dealing with emotions (including stress, trauma). As Jan Bielecki points out, disabilities may produce permanent changes in one's personality. According to him, people with congenital disabilities, in contrast to people with acquired disabilities, have an increased level of anxiety, decreased sense of security, and an increased level of aggressiveness (Bielecki 2009). Health consequences relate to the need for medical appointments, rehabilitation, and using medication and professional and financial consequences entail the need to accept a low-status job, sometimes incompatible with the interests and aspirations of a person, professional retraining, or even giving up work. This is related to the economic situation of a person with a disability and their family, including expenses incurred for rehabilitation, and adapting household equipment (purchase of a specialist bed, bathroom equipment, etc.). Social effects include a limited circle of social interactions, and more difficulties in communicating with others. It should be noted that these categories of consequences are not unrelated to each other. For example, health consequences have an impact on one's finances and social consequences are associated with psychological ones.

The consequences of experiencing disabilities are reinforced by the many negative generalizations about it. In Poland, it is said that people with mobility disabilities are aggressive towards their environment, and blind people are mysterious and lack of sense of humour. People speak about the intellectually disabled stereotypically as being eternal children, while deaf people are considered to be intellectually impaired or anti-social (Błeszyńska 2001).

In Poland, the medical model of disability consisting in perceiving it from a health perspective (and therefore limitations in independent functioning), by virtue of the Convention on the Rights of Persons with Disabilities (Journal of LawsO.J. of 2012 item 1169), has been displaced by the social model. In this approach, the autonomy of the disabled person and their subjectivity are highlighted. The Convention, as an international document, obliges Poland to guarantee people with disabilities the use of all freedoms and human rights. However, practitioners specializing in disabilities emphasize that despite the fact that the Convention was ratified in October 2012, many of its areas still need to be strengthened. The solutions regarding the implementation of the right to independent living (including the choice of place of residence, inclusion in the local community), self-determination, full legal capacity, inclusive education, starting a family and having children, working on the open labour market, appropriate living conditions, or access to information seem to be particularly important here (Zima-Parjaszewska 2019).
Given the consequences of experiencing disabilities and related stereotypes, the issue of the dignity of a disabled person is particularly important. In Polish literature on the subject, one can find postulates about building disabled people's sense of dignity. For example, it is recommended to provide emotional and social support in all areas of life through the family and educational environment, formation of an assertive attitude, and the transfer of knowledge about their rights (Bielecki 2009). However, there are definitely no studies, especially non-empirical work that would present issues of understanding and experiencing dignity by people with disabilities. In fact, the only extensive study on this subject was research carried out by Bernadetta Szczupał (2009) in 20032006 among 344 students with mobility disabilities aged 1719. The author tried to find answers to questions, among others, about how young people with disabilities define dignity, how they experience their sense of dignity, and what are its determinants?

The material she collected shows that for many participants, her research on the sense of dignity is not affected by the fact of being disabled, but by the way of being perceived and treated by others. Negative comments, judgement, and experiences caused a sense of being inferior to non-disabled people, which in turn led to a loss of self-dignity. In the statements analysed by B. Szczupal, situations in which "the normal ones were staring at" the people with disabilities were mentioned. It is interesting that there were people among the respondents who, despite their disability, did not experience this. They were aware of their strengths and weaknesses and they accepted them. This state changed as a result of inappropriate behaviours and assessments issued by non-disabled people (Szczupał 2009).

The respondents understood dignity as a set of rules according to which a person should live (e.g. respect for others, being honest, tolerant) as rights for everyone (Szczupał 2009). The respondents' experience of dignity was affected by barriers encountered in everyday functioning, which forced them to ask for help (it is worth recalling the provisions of the Convention on the Rights of Persons with Disabilities, including those concerning the right to independent living). As an 18-year-old participant of the study said: "And then you usually have to hide this dignity and simply ask for help in overcoming these obstacles, because everyone pretends not to see me and that it does not concern them or that maybe someone will feel sorry and help me (...) (broke down in tears?)".

The dignity of the surveyed people with disabilities was identified by some of them with the meaning of life. The search for the meaning of suffering, an explanation of "why did this happen?", believing in the meaning of such a fate were treated as values shaping it. The possibility of finding employment also has an impact on their experience of disabilities. Work and earnings obtained thanks to it will allow, in the opinion of some young people, to maintain a decent life and independence (Szczupał 2009). 
The contents cited in this part of the article refer to the understanding of the concept of dignity by people (young people) with disabilities and the factors shaping it. However, they do not include information on the sense of personal dignity. This problem is not yet recognized. This article is therefore the very beginning of the exploration and dissemination of this issue.

\section{Methodology}

Profile of Participants The research was carried out among 98 people with disabilities including 53 women and 45 men. The ages of participants of the study group ranged between 19 and 55 years, the average age of the study group was 35 . Taking into account the marital status of the respondents, 36 of them are single (36.7\%), 24 are married (24.5\%), 24 of the respondents $(24.5 \%)$ live in an informal relationship, and 12 are divorced (12.2\%), and two people (2.2\%) are widows/widowers. With regard to education, one-third of those surveyed have elementary education (33.7\%), 38.8\% people have vocational education, $22.4 \%$ people have secondary education, and $5.1 \%$ of those participating in the study have higher education. The respondents were also asked about their employment activity. Many of the respondents were employed $(41.8 \%)$. Nearly $25 \%$ of the respondents receive a disability pension and work. One in five people surveyed are unemployed, and $13.3 \%$ wholly depend on the disability pension for income support. The last sociodemographic variable considered in the study was the time of becoming disabled. As many as 65 people surveyed $(66.3 \%)$ were born with disabilities, while $33.7 \%$ are people who acquired a disability at some point throughout their lifetime (due to an illness or an accident).

Materials The empirical material was collected by applying a diagnostic survey carried out by using questionnaires. The research tool was the Sense of Self-Dignity Questionnaire (KPWG-3) created by Stanisława Steuden and Paweł Brudek. The questionnaire consists of 36 statements that form four dimensions: Cognitive, Loss, Relational and Experience, and the task of the surveyed person was to make an assessment on a five-point scale, to what extent the person agrees with each of them. The cognitive dimension determines to what extent the individual considers the sense of their own dignity as a way of perceiving themselves and their own functioning. The dimension of loss reflects the extent to which the loss of self-esteem affects functioning in the emotional sphere and in relation to oneself. The relational dimension reveals the extent to which a person experiences a sense of self-esteem by creating and maintaining relationships with other people, whereas the experience dimension determines to what extent a person reflects on his or her own dignity in difficult or conflict situations in which there is a risk of violating self-esteem, and in moments and decisions of vital importance (Steuden 2011). Reliability ( $\alpha$-Cronbach's) indicators for particular scales range from .87 to .91 (Brudek and Steuden 2017).

Analysis of the literature revealed that one's sense of dignity is a complex construct and thus difficult to operationalize. Therefore, the issue of the sense of self-dignity is above all a subject of theoretical reflection rather than empirical research. The absence of tools with satisfactory psychometric parameters used for the psychological measurement of one's sense of selfdignity both in Poland and Europe confirms this fact. Attempts at creating this type of method, although they deserve mentioning, are more suited for qualitative analysis. As a result, it was decided to conduct this research by using the Sense of SelfDignity Questionnaire created by Brudek and Steuden. This tool has satisfactory psychometric parameters, both in terms of reliability and theoretical accuracy. In addition, it allows for measuring the four-factor structure of the sense of selfdignity expressed in the four dimensions analysed: Cognitive, Loss, Relational, and Experience. The statistical analysis was carried out using the SPSS Statistics 25.0 program.

Method of Data Collection The empirical material was collected from February to April 2019 from among people with mobility disabilities (congenital and acquired). The people surveyed were beneficiaries of the Hej, Koniku! non-governmental organization. Several factors determined its choice as the place for carrying out the study. Firstly, the Foundation's many years of experience in conducting activities dedicated to people with various forms of disabilities. Secondly, the scope of activity, which includes career counselling, rehabilitation, and family assistantship. Thirdly, the Foundation's co-operation with the organizational units of social services and other NGOs. The time-frame of the study was set together with the Foundation's career counsellor and social worker, and its beneficiaries. Since the researchers wanted the study to take place in friendly and safe conditions for the participants, the questionnaires were distributed in the presence of two of the Foundation's employees at weekly meetings and workshops. Each questionnaire contained detailed instructions and the participants were informed about the purpose of the study, its anonymous and volunteer nature, the possibility of interrupting participation at any time, and the manner in which the findings would be used. The beneficiaries willingly took part in the study and claimed that they had never participated in an exploratory study on the sense of dignity.

Analysis of Data The first step in analysing the data was determining the average values, the minimum and maximum results, and the standard deviation of specific dimensions of the sense of personal dignity in the surveyed group of people with mobility disabilities. Additionally, Student's $t$ distribution for independent samples and the Kurskal-Wallis tests were applied, which allow for determining whether the 
analysed sociodemographic changes differentiate the sense of self-dignity in the participants in a statistically significant manner.

Limitations Although the presented study is innovative, because it addresses an issue that has not been well recognized, it has at least two limitations. One of them is the selection of samples, which do not meet the requirements of representativeness and is limited to only one type of disability - mobility. It would be interesting from the cognitive perspective to conduct a similar analysis among people with sensory disabilities (the blind, and the deaf).

The second limitation is the application of the quantitative approach. In Poland and abroad, there are few studies (and few tools) that address the issue at hand. In the future, it would be worth considering supplementing the exploration with qualitative studies in which the respondents would independently present (in structured interviews) dimensions of self-esteem.

\section{Results and Discussion}

The first step in the analysis was to determine the average values for individual dimensions of the sense of personal dignity in the surveyed group of people with disabilitiesdescriptive statistics. Detailed data are included in Table 1.

The data contained in Table 1 show that in terms of the cognitive dimension, the minimum result is 12 points, while the highest was 35 points. The average result in the group of people with disabilities for the cognitive dimension is $M=23.02$ points. Taking into account the loss of the sense of personal dignity of people with disabilities, the minimum result is 11 points and the maximum is 41 , while the average for this dimension is $M=$ 27.70 points. While analysing the relational dimension of the sense of personal dignity, it was noted that the minimum result is 7 points, and the maximum 20 points, the average for this dimension in the study group is $M=13.64$ points. The analysis of the relational dimension of the sense of personal dignity indicated that the minimum result is 9 points, and the maximum 27 points, while the average for this dimension in the study group is $M=13.64$ points. The average total result of the personal dignity dimension in the surveyed group of the people with disabilities is $M=133.76$ points.
The next step was to identify if sociodemographic variables such as sex, time of the disability occurrence (congenital vs acquired), employment activity, and education impact the level of the sense of personal dignity among the people with disabilities participating in the study. For this purpose, Student's $t$ test for independent samples and the KruskalWallis test were used, assuming a significance level of $p<$ 0.05 . Detailed data are presented in Tables $2,3,4$, and 5 .

The results of the research presented in Table 2 show that there are statistically significant differences between the surveyed women and men with disabilities in three dimensions of the sense of personal dignity. While analysing the loss dimension, it was noted that the surveyed women obtained a higher average score than disabled men $(p=0.009)$. This indicates that women with disabilities have a greater sense of loss of personal dignity; hence, this may be reflected in their emotional functioning and self-perception (impact on self-appraisal and self-esteem). Taking into account the relational dimension, disabled men obtained a significantly higher average score compared with women $(p=0.001)$. This is related to the fact that the smaller possibility of establishing and maintaining interpersonal relations will result in a decrease in the sense of personal dignity in the examined men with disabilities and would translate into psychosocial functioning. As far as the experience dimension is concerned, the surveyed men with disabilities achieved a higher average score $(M=18.49)$ than the surveyed women $(M=17.11)$; moreover, the evidenced difference is statistically significant $(p=0.028)$. Therefore, it can be assumed that men more often think about the impact of their current life situation on their sense of personal dignity, in particular when they leave their family homes and start running their own household. This is the result of social roles performed by both sexes. It is assumed that it is easier for women to take care of household responsibilities as they are prepared for this in the process of socialization and upbringing.

On the other hand, in terms of the cognitive dimension of the sense of personal dignity, the surveyed men achieved a higher average score $(M=23.80)$ than the surveyed women $(M=22.36)$ and the difference is close to the statistically significant result at the level of $p<0.05$. This means that the surveyed men with disabilities give a greater importance to the sense of dignity than women, in relation to self-perception and self-functioning. In terms of the overall result, the
Table 1 Sense of the personal dignity of the people with disabilities - descriptive statistics

\begin{tabular}{lcccc}
\hline $\begin{array}{l}\text { Dimensions of the personal } \\
\text { dignity }\end{array}$ & $\begin{array}{l}\text { Minimum } \\
\text { result }\end{array}$ & $\begin{array}{l}\text { Maximum } \\
\text { result }\end{array}$ & $\begin{array}{l}\text { Average } \\
\text { result }\end{array}$ & $\begin{array}{l}\text { Standard } \\
\text { deviation-Sd }\end{array}$ \\
\hline Cognitive dimension & 12.00 & 35.00 & 23.02 & 4.11 \\
Loss dimension & 11.00 & 41.00 & 27.70 & 5.91 \\
Relational dimension & 7.00 & 20.00 & 13.64 & 2.66 \\
Experience dimension & 9.00 & 27.00 & 17.74 & 3.11 \\
Total result & 108.00 & 174.00 & 133.76 & 10.71 \\
\hline
\end{tabular}


Table 2 Sense of the personal dignity vs sex of the people with disabilities

\begin{tabular}{lllll}
\hline Dimensions of the personal dignity & $\begin{array}{l}\text { W-women } \\
(M)\end{array}$ & $\begin{array}{l}\mathrm{M}-\mathrm{men} \\
(M)\end{array}$ & $\begin{array}{l}\text { Student's } t \text { test } \\
(t)\end{array}$ & $\begin{array}{l}\text { Level of significance } \\
(p)\end{array}$ \\
\hline Cognitive dimension & 22.36 & 23.80 & -1.749 & $0.084 \sim$ \\
Loss dimension & 29.13 & 26.02 & 2.676 & $0.009^{*}$ \\
Relational dimension & 12.83 & 14.60 & -3.469 & $0.001^{* *}$ \\
Experience dimension & 17.11 & 18.49 & -2.228 & $0.028^{*}$ \\
Total result & 134.49 & 132.91 & 0.726 & 0.470 \\
\hline
\end{tabular}

$* p<0.05 ; * * p<0.001 ; \sim$, near-significant level observed differences between the surveyed women and men with disabilities proved to be statistically insignificant, whereby disabled women have a higher sense of personal dignity $(M=134.49)$ than the surveyed men $(M=132.91)$.

The data presented in Table 3 show that no statistically significant difference $(p<0.05)$ was found in any of the analysed dimensions of the sense of personal dignity or in the overall result. At the same time, people with congenital disabilities achieved a higher average score $(M=134.00)$ than people who had a disability as a result of an illness or an accident $(M=$ 133.30), which may mean that people with an "acquired" disability identify being physically fit with personal dignity and its loss with a subjective sense of decreased dignity. In the cognitive, loss, and experience dimensions, people with an "acquired" disability are characterized by a higher sense of dignity, while only in the relational dimension people with a "congenital" disability have a higher sense of dignity. This may indicate that they perceive their disability as a limiting factor in establishing and maintaining interpersonal relationships and may result in difficulties in psychosocial functioning.

This is confirmed, for example, by the authors' research on the sense of personal dignity of seniors. They pointed out that feelings of losing one's personal dignity increase with age, which is associated with, among others, current life circumstances including restricted psychical activity or a greater occurrence of somatic diseases (Grudziewska and Mikołajczyk 2019, p. 165).

The results presented in Table 4 indicate that the employment activity of the surveyed people with disabilities does not significantly differentiate their sense of personal dignity as far as the statistics is concerned. While analysing the individual dimensions of the sense of personal dignity, it can be noticed that the disabled receiving a pension and at the same time undertaking employment have the highest sense of dignity in the following dimensions: cognitive, relational, and experience. On the other hand, the disabled people who are unemployed have a low self-esteem in the experience and cognitive dimension, which may mean that professional work is important for perceiving oneself and one's own functioning.

While analysing the sense of self-dignity of people with physical disabilities, four separate levels of education were distinguished: elementary, vocational, secondary, and higher. The application of the Kruskal-Wallis test allows stating that the level of education of the surveyed people with disability differentiates the intensity within two dimensions of the sense of personal dignity, that is to say the cognitive and experience dimensions, and in terms of overall result. As far as the cognitive dimension is concerned, the highest average result was recorded in the group of people with vocational education, while the lowest in people with secondary education. In the dimension of experience, the highest average result was achieved by people with secondary education, while the lowest were people with higher education. In terms of the overall result of the sense of personal dignity, the highest average result was obtained by people with secondary education, while the lowest by people with higher education. However, in the relational dimension, a tendency similar to the level of significance was observed.
Table 3 Sense of the personal dignity vs time of the disability occurrence

\begin{tabular}{lllll}
\hline $\begin{array}{l}\text { Dimensions of the personal } \\
\text { dignity }\end{array}$ & $\begin{array}{l}\text { Congenital } \\
\text { disability } \\
(M)\end{array}$ & $\begin{array}{l}\text { Acquired } \\
\text { disability } \\
(M)\end{array}$ & $\begin{array}{l}\text { Student's } t \\
\text { test } \\
(t)\end{array}$ & $\begin{array}{l}\text { Level of } \\
\text { significance } \\
(p)\end{array}$ \\
\hline Cognitive dimension & 23.01 & 23.03 & -0.017 & 0.987 \\
Loss dimension & 27.25 & 28.61 & -1.077 & 0.284 \\
Relational dimension & 13.80 & 13.33 & 0.820 & 0.414 \\
Experience dimension & 17.71 & 17.82 & -0.166 & 0.869 \\
Total result & 134.00 & 133.30 & 0.303 & 0.763 \\
\hline
\end{tabular}

$* * p<0.05$ 
Table 4 Sense of dignity and employment of the respondents

\begin{tabular}{|c|c|c|c|c|c|c|}
\hline $\begin{array}{l}\text { Dimensions of the personal } \\
\text { dignity }\end{array}$ & $\begin{array}{l}\text { Employment } \\
\text { activity }\end{array}$ & $N$ & Result & $\begin{array}{l}\text { Kruskal-Wallis } \\
\text { test } \\
H\end{array}$ & df & $p$ \\
\hline \multirow[t]{4}{*}{ Cognitive dimension } & Employed & 41 & 47.00 & \multirow[t]{4}{*}{2.754} & \multirow[t]{4}{*}{3} & \multirow[t]{4}{*}{0.431} \\
\hline & Unemployed & 20 & 45.98 & & & \\
\hline & Pension & 13 & 47.50 & & & \\
\hline & $\begin{array}{l}\text { Pension+ } \\
\text { employment }\end{array}$ & 24 & 57.79 & & & \\
\hline \multirow[t]{4}{*}{ Loss dimension } & Employed & 41 & 47.66 & \multirow[t]{4}{*}{0.653} & \multirow[t]{4}{*}{3} & \multirow[t]{4}{*}{0.888} \\
\hline & Unemployed & 20 & 47.90 & & & \\
\hline & Pension & 13 & 53.08 & & & \\
\hline & $\begin{array}{l}\text { Pension+ } \\
\text { employment }\end{array}$ & 24 & 52.04 & & & \\
\hline \multirow[t]{4}{*}{ Relational dimension } & Employed & 41 & 48.57 & \multirow[t]{4}{*}{1.303} & \multirow[t]{4}{*}{3} & \multirow[t]{4}{*}{0.728} \\
\hline & Unemployed & 20 & 50.35 & & & \\
\hline & Pension & 13 & 43.12 & & & \\
\hline & $\begin{array}{l}\text { Pension+ } \\
\text { employment }\end{array}$ & 24 & 53.83 & & & \\
\hline \multirow[t]{4}{*}{ Experience dimension } & Employed & 41 & 46.62 & \multirow[t]{4}{*}{6.314} & \multirow[t]{4}{*}{3} & \multirow[t]{4}{*}{0.097} \\
\hline & Unemployed & 20 & 42.23 & & & \\
\hline & Pension & 13 & 47.35 & & & \\
\hline & $\begin{array}{l}\text { Pension+ } \\
\text { employment }\end{array}$ & 24 & 61.65 & & & \\
\hline \multirow[t]{4}{*}{ Total result } & Employed & 41 & 51.51 & \multirow[t]{4}{*}{2.048} & \multirow[t]{4}{*}{3} & \multirow[t]{4}{*}{0.562} \\
\hline & Unemployed & 20 & 52.33 & & & \\
\hline & Pension & 13 & 52.08 & & & \\
\hline & Pension+empoyed & 24 & 42.31 & & & \\
\hline
\end{tabular}

$p<0.05$

\section{Conclusions}

The aim of the presented research was to determine the sense of personal dignity among people with disabilities, with particular emphasis on such sociodemographic variables as sex, time of the disability occurrence (congenital vs acquired), employment activity, and education.

The statistical analysis revealed that the surveyed women are characterized by a higher sense of personal dignity compared with men in terms of loss $(p<0.05)$ and the general result, while male respondents have a higher sense of personal dignity in the following dimensions: relational $(p<0.001)$ and experience $(p<0.05)$. Moreover, taking into account the time of occurrence of the disability creation, that is to say "congenital disability" vs "acquired disability", there are no statistically significant differences $(p>0.05)$. Furthermore, the employment activity of the surveyed people with disabilities does not significantly differentiate their sense of personal dignity ( $p>0.05)$. However, as far as the education of the surveyed persons with disabilities is concerned, statistically significant differences were noted in the following dimensions: cognitive $(p<0.05)$ and experience $(p<0.001)$ and in the total result $(p<0.05)$. The obtained test results cannot be generalized for the entire population of people with disabilities in Poland, but they can serve as the basis for conducting research on a larger population of disabled people. From a cognitive point of view, it is important to indicate the factors that determine a sense of personal dignity (apart from sociodemographic variables, personal resources such as selfesteem, self-efficacy, value system, or sense of responsibility should also be included, as well as social variables related to the assistance and support system).

The studied research problems are rarely undertaken and, therefore, it seems to be interesting both from the cognitive and the implication point of view. Everyone deserves to be treated with dignity regardless of their life situation, health, appearance, place of residence, or economic status. Dignity is a feature that everyone is entitled to, regardless of their circumstances, and no one can deprive us of it in objective terms, because it results from the fact of being born a human being. However, in the subjective dimension, which is the subject of this research, a person can be deprived of their sense of dignity. When working with disabled people, one should pay great attention to their sense of personal dignity and undertake such activities, which will often restore and raise their sense of dignity. It is necessary to create such conditions in which people with disabilities could have a sense of being valuable 
Table 5 Sense of the personal dignity vs education of the people with disabilities

\begin{tabular}{|c|c|c|c|c|c|c|}
\hline $\begin{array}{l}\text { Dimensions of the personal } \\
\text { dignity }\end{array}$ & $\begin{array}{l}\text { Level of } \\
\text { education }\end{array}$ & $N$ & Result & $\begin{array}{l}\text { Kruskal-Wallis } \\
\text { test } \\
\mathrm{H}\end{array}$ & $\mathrm{df}$ & $p$ \\
\hline \multirow[t]{3}{*}{ Cognitive dimension } & $\begin{array}{l}\text { Elementary } \\
\text { Vocational }\end{array}$ & $\begin{array}{l}32 \\
38\end{array}$ & $\begin{array}{l}53.13 \\
54.37\end{array}$ & \multirow[t]{3}{*}{7.884} & \multirow[t]{3}{*}{3} & \multirow[t]{3}{*}{$0.048 *$} \\
\hline & Secondary & 22 & 34.80 & & & \\
\hline & Higher & 5 & 44.30 & & & \\
\hline \multirow[t]{3}{*}{ Loss dimension } & $\begin{array}{l}\text { Elementary } \\
\text { Vocational }\end{array}$ & $\begin{array}{l}32 \\
38\end{array}$ & $\begin{array}{l}49.25 \\
49.43\end{array}$ & \multirow[t]{3}{*}{2.534} & \multirow[t]{3}{*}{3} & \multirow[t]{3}{*}{0.469} \\
\hline & Secondary & 22 & 44.02 & & & \\
\hline & Higher & 5 & 66.00 & & & \\
\hline \multirow[t]{3}{*}{ Relational dimension } & $\begin{array}{l}\text { Elementary } \\
\text { Vocational }\end{array}$ & $\begin{array}{l}32 \\
38\end{array}$ & $\begin{array}{l}49.00 \\
56.43\end{array}$ & \multirow[t]{3}{*}{6.641} & \multirow[t]{3}{*}{3} & \multirow[t]{3}{*}{$0.084 \sim$} \\
\hline & Secondary & 22 & 37.68 & & & \\
\hline & Higher & 5 & 42.30 & & & \\
\hline \multirow[t]{4}{*}{ Experience dimension } & Elementary & 32 & 51.64 & \multirow[t]{4}{*}{17.039} & \multirow[t]{4}{*}{3} & \multirow[t]{4}{*}{$0.001 * *$} \\
\hline & Vocational & 38 & 58.57 & & & \\
\hline & Secondary & 22 & 28.23 & & & \\
\hline & Higher & 5 & 50.80 & & & \\
\hline \multirow[t]{4}{*}{ Total result } & Elementary & 32 & 46.83 & \multirow[t]{4}{*}{12.620} & \multirow[t]{4}{*}{3} & \multirow[t]{4}{*}{$0.006^{*}$} \\
\hline & Vocational & 38 & 41.64 & & & \\
\hline & Secondary & 22 & 67.16 & & & \\
\hline & Higher & 5 & 38.90 & & & \\
\hline
\end{tabular}

$* p<0.05 ; * * p<0.001 ; \sim$, near-significant level and having influence on their decisions and surrounding reality.

Such conditions include:

- Increasing the participation of people with disabilities on the labour market,

- Raising their quality of life by removing architectural barriers,

- Improving access to public facilities and cultural centres (theatres, museums and cinemas),

- Raising social awareness by eliminating stereotypes and prejudices concerning people with psychical disabilities (e.g. by conducting anti-discrimination lessons in educational centres, conducting national social campaigns, and promote awareness of the needs of people with disabilities).

- Implementing the proposed actions may contribute to raising the sense of self-dignity of people with physical disabilities.

At this point, the difference between human dignity, identified with human rights inherent to all and inalienable, and personal dignity - a character trait related to one's self-esteem-must be emphasized once again. Implementing the proposed actions lies outside the competence of social workers. This is the task of broadly understood social policy which includes social assistance, and requires a systemic approach to people with disabilities including education and the labour market. When working with disabled people, the role of a social worker should consist in indicating ways of improving their life situation. It is not only a question of improving living conditions (implemented by a catalogue of cash benefits and material assistance) but also of restoring self-efficacy, which is one of the predictors of self-esteem (Grudziewska and Mikołajczyk 2020), and strengthening the right to self-determination. It often happens that people with disabilities do not have the opportunity to think for themselves and about themselves as this is done for them, because it is easier for their loved ones. Placed in an assistance system, in some way, they have automatically lost themselves together with their self-esteem and dignity. Social work with people with disabilities is intended to stimulate their independence. An optimal situation will be when their family and local community are involved in their activities.

In the practise of Polish social work, a shift from the charity model to supportive actions and also a move from surrounding passive individuals with assistance to their activation can be observed (Podgórska-Jachnik 2014:32). Such activation will only be fully possible once the issues of human and personal dignity are taken into consideration.

\section{Compliance with Ethical Standards}

Conflict of Interest The authors declare that they have no conflict of interest. 
Open Access This article is licensed under a Creative Commons Attribution 4.0 International License, which permits use, sharing, adaptation, distribution and reproduction in any medium or format, as long as you give appropriate credit to the original author(s) and the source, provide a link to the Creative Commons licence, and indicate if changes were made. The images or other third party material in this article are included in the article's Creative Commons licence, unless indicated otherwise in a credit line to the material. If material is not included in the article's Creative Commons licence and your intended use is not permitted by statutory regulation or exceeds the permitted use, you will need to obtain permission directly from the copyright holder. To view a copy of this licence, visit http://creativecommons.org/licenses/by/4.0/.

\section{References}

Barlik, M., Cichy, H., Jacyków, D., Lewandowska, B., Mirosław, J., Siwiak, K., Wagrowska, U., Statystyczny, G. U., Departament Badań Społecznych i Warunków Życia (2017). Budżety Gospodarstw Domowych w 2016 r., Warszawa, https://stat.gov.pl/ obszary-tematyczne/warunki-zycia/dochody-wydatki-i-warunkizycia-ludnosci/budzety-gospodarstw-domowych-w-2016-r-,9,11. html. Accessed: 15 June 2019.

Bielecki, J. (2009). O rozwój godności osoby dziecka niepełnosprawnego. In A. Popławska (Ed.), Podmiotowość w praktyce edukacyjnej: konteksty, działania, zagrożenia (pp. 201208). Białystok: Wydawnictwo Niepaństwowej Wyższej Szkoły Pedagogicznej.

Błeszyńska, K. (2001). Niepetnosprawność a struktura identyfikacji społecznych. Warszawa: Wydawnictwo Akademickie Żak.

Brudek, P., \& Steuden, S. (2017). Predyktory poczucia własnej godności. Badania osób w okresie późnej dorosłości. Psychoterapia, 4(183), 81-92.

Charter of Fundamental Rights of the European Union in 2010, Official Journal of the European Union 2010, 2010/C83/02.

Chudy, J. (2005). Godność człowieka wartością ontyczno-wychowawczą. In M. Kalinowski (Ed.), Wzrastanie czlowieka $w$ godności, miłości $i$ miłosierdziu (pp. 83-91). Lublin: Wydawnictwo Naukowego Katolickiego Uniwersytetu Lubelskiego.

Constitution of the Republic of Poland from 1997, DzU. z 1997 r, nr 78, poz 483.

Convention on the Rights of Persons with Disabilities; O.J. of 2012 item 1169.

Convention on the Rights of the Child adopted by the General Assembly of the United Nations on November 20, 1989.

de Tchorzewski, A. M. (2016). Metafizyka i doświadczanie godności. In I. Jazukiewicz \& A. M. de Tchorzewski (Eds.), Godność jako wartość i problem edukacyjny. Szczecin: Wydawnictwo Naukowe Uniwersytetu Szczecińskiego.

Dykcik, W. L. (2009). Problemy autonomii, integracji społecznej i normalizacji życia osób niepełnosprawnych w środowisku. In W. Ł. Dykcik (Ed.), Pedagogika specjalna (pp. 355-378). Wydawnictwo UAM.

Friedman, C. (2018). R-E-S-P-E-C-T: the relationship between being respected and quality of life of disabled people. Disability Studies Quarterly, 38(2). https://doi.org/10.18061/dsq.v38i2.6168 http:// dsq-sds.org/article/view/6168/4908. Accessed: 26 September 2019.

Grudziewska, E., \& Mikołajczyk, M. (2019). Poczucie godności osobistej seniorów - komunikat z badań. Niepetnosprawność. Dyskursy Pedagogiki Specjalnej, 35, 156-168.
Grudziewska E., \& Mikołajczyk M. (2020). Uwarunkowania poczucia własnej godności u osób z niepetnosprawnościa ruchowa komunikat z badań. In: Niepełnosprawność. Dyskursy Pedagogiki Specjalnej, (in review).

Mariański, J. (2016). Godność ludzka jako wartość społeczno-moralna: mit czy rzeczywistość? Studium interdyscyplinarne, Wydawnictwo Adam Marszałek, Torun.

Mikrut, A. (2016). O promowaniu godności człowieka w ramach Konwencji o Prawach Osób Niepełnosprawnych. Rocznik Komisji Nauk Pedagogicznych, LXIX, 105-121.

Misztal, B. A. (2012). The idea of dignity: Its modern significance. European Journal of Social Theory, 16(1), 101-121. https://doi. org/10.1177/1368431012449237.

Pinilla-Roncancio, M. (2015), Disability and poverty: two related conditions. A review of the literature; Revista de la Facultad de Medicina, Vol.63, Supl.1, p.113-123, DOI: https://doi.org/10.15446/ revfacmed.v63n3sup.50132.

Podgórska-Jachnik, D. (2014). Praca socjalna z osobami z niepetnosprawnościami i ich rodzinami. Warszawa: Centrum Rozwoju Zasobów Ludzkich.

Protocol No. 13 to the Convention of the Protection of Human Rights and Fundamental Freedoms concerning the abolition of the death penalty in all circumstances, done at Vilnius on May 3, 2002.

Stein, M. A. (2007). Disability human rights. California Law Review, 95(75), 75-122. https://doi.org/10.15779/Z38XQ4Z.

Steuden, S., (2011), Psychologia starzenia się i starości, Warszawa: Wydawnictwo PWN.

Szczupał, B. (2009). Godność osoby z niepetnosprawnościa. Studium teoretyczno-empiryczne poczucia godności młodzieży z dysfunkcja ruchu. Kraków: Wydawnictwo Naukowe Akapit.

Universal Declaration of Human Rights of the United Nations of December 10, 1948.

Uwell, M., Braarvig, J., Brownsword, R., \& Mieth, D. (Eds.). (2012). The Cambridge handbook of human dignity. Interdisciplinary perspectivesord. Cambridge: Cambridge University Press.

Wolski, P. (2013). Niepetnosprawność ruchowa. Między diagnoza a działaniem. Warszawa: Centrum Rozwoju Zasobów Ludzkich.

World Health Organization. (2011), World report on disability. https:// www.who.int/disabilities/world_report/2011/report.pdf. Accessed: 25 June 2019.

Wysocka, A., Szelfer, S., Antczak, R., Bielska, M., \& Piszcz, A. (2011). Ludność i gospodarstwa domowe. Stan i struktura spotecznoekonomiczna. Narodowy Spis Powszechny Ludności i Mieszkań 2011, Główny Urząd Statystyczny, Departament Badań Demograficznych i Rynku Pracy, Warszawa. https://stat.gov.pl/ spisy-powszechne/nsp-2011/nsp-2011-wyniki/ludnosc-igospodarstwa-domowe-stan-i-struktura-spoleczno-ekonomicznaczesc-i-ludnosc-nsp-2011,11,1.html. Accessed: 15 June 2019.

Zima-Parjaszewska, M. (2019). Prawo do niezależnego życia osób z niepełnosprawnościami w praktyce organów pomocy społecznej. In E. Grudziewska, M. Mikołajczyk, \& J. Zozula (Eds.), Pomoc społeczna i praca socjalna $w$ dobie dynamicznych przemian społecznych (pp. 95-109). Warszawa: Wydawnictwo Akademii Pedagogiki Specjalnej.

Publisher's Note Springer Nature remains neutral with regard to jurisdictional claims in published maps and institutional affiliations. 